\title{
Diagnostic yield of conventional transbronchial needle aspiration biopsy (C-TBNA) without an on-site cytopathologist: Experience of 363 procedures in 219 patients
}

Özge ÖZTÜRK ${ }^{1}$

Abdulsamet SANDAL ${ }^{1}$

Sevilay KARAHAN ${ }^{2}$

Berrin ER ${ }^{1}$

Sevgen ÖNDER ${ }^{3}$

Deniz KÖKSAL ${ }^{1}$

Emin MADEN ${ }^{1}$

Salih EMRi ${ }^{1}$

\footnotetext{
${ }^{1}$ Department of Chest Diseases, Faculty of Medicine, Hacettepe University, Ankara, Turkey

${ }^{1}$ Hacettepe Üniversitesi Tıp Fakültesi, Göğüs Hastalıkları Anabilim Dalı, Ankara, Türkiye

2 Department of Biostatistics, Faculty of Medicine, Hacettepe University, Ankara, Turkey

2 Hacettepe Üniversitesi Tıp Fakültesi, Biyoistatistik Anabilim Dalı, Ankara, Türkiye

${ }^{3}$ Department of Pathology, Faculty of Medicine, Hacettepe University, Ankara, Turkey

${ }^{3}$ Hacettepe Üniversitesi Tıp Fakültesi, Patoloji Anabilim Dalı, Ankara, Türkiye
}

\section{SUMMARY}

Diagnostic yield of conventional transbronchial needle aspiration biopsy (C-TBNA) without an on-site cytopathologist: Experience of 363 procedures in 219 patients

Introduction: Conventional transbronchial needle aspiration biopsy (C-TBNA) is a technique in evaluating mediastinal/hilar lymph nodes (LN). We aimed to investigate diagnostic yield (DY) and safety of C-TBNAs performed in a single university clinic.

Patients and Methods: We retrospectively reviewed 363 consecutive C-TBNA procedures in 219 patients. The DY and its relationship with location, shortest diameter, SUVmax of $L N$, and number of sampled stations were evaluated.

Results: Procedures were diagnostic in 257 (71\%) LNs. The most common diagnoses were malignancy $(n=109.30 \%)$ and granulomatous inflammation $(n=68,18.7 \%)$. The ratio of patients with at least one diagnostic cytology result was $77 \%(n=168)$. DY was significantly increased with the increased number of sampled LNs $(p=0.033)$ and larger LN diameter $(p<0.001)$. Sensitivity, specificity, positive, and negative predictive values were $83.3 \%, 43.2 \%, 79.6 \%$, and $49.3 \%$ respectively for cut-off LN diameter of $11.5 \mathrm{~mm}$. There was nearly a significant relationship between DY and SUVmax ( $p=0.05$, cut-off= 4.8). The highest DY was in subcarinal LN (77.4\%). No major complications were recorded.

Conclusion: The DY of C-TBNA was $71 \%$. The ratio of the patients with at least one diagnostic cytology result was $77 \%$. The most common diagnoses were malignancy and granulomatous inflammation. The DY of C-TBNA was increased with the increased number of sampled LNs, larger LN diameter, and increased SUVmax. C-TBNA is a safe procedure.

Key words: C-TBNA, mediastinum, lymph nodes, malignancy, granulomatous inflammation

\section{ÖZET}

Konvansiyonel transbronşiyal iğne aspirasyon biyopsisinin (K-TBiA) tanısal değeri: 219 hastada 363 işlemin deneyimi

Giriș: Konvansiyonel transbronşiyal iğne aspirasyon biyopsisi (K-TBIA), mediyastinal/hiler lenf nodlarının (LN) değerlendirmesinde kullanılan bir tekniktir. Bu çalısmada bir üniversite kliniğinde yapılan K-TBiA'ların tanısal değeri ve güvenilirliğinin araştırılması amaçlandı.

\section{Yazışma Adresi (Address for Correspondence)}

Dr. Abdulsamet SANDAL

Hacettepe Üniversitesi Tıp Fakültesi, Göğüs Hastalıkları Anabilim Dalı, ANKARA - TURKEY

e-mail: asandal@hotmail.com.tr 
Hastalar ve Metod: Çalışmada 219 hastaya yapılan ardışık 363 K-TBiA işlemi retrospektif olarak incelendi. Tanısal başarının lokalizasyon, en kısa çap, SUVmaks değeri ve örneklenen istasyon sayısı ile ilişkisi değerlendirildi.

Bulgular: iki yüz elli yedi (\%71) LN'de işlem tanısaldı. En sık tanılar malignite ( $n=109, \% 30)$ ve granülomatöz inflamasyondu ( $n=$ $68, \% 18.7)$. En az bir tanısal sitoloji sonucu olan hasta oranı \% $77(n=168)$ idi. Örneklenen lenf nodlarının sayısı ( $p=0.033)$ ve çapı $(p<0.001)$ arttıkça tanısal başarı anlamlı şekilde artmaktaydı. Lenf nodu çapı $11.5 \mathrm{~mm}$ ve üzerinde olduğunda tanısal duyarılık, özgüllük, pozitif ve negatif prediktif değerler sırasıly \% 83.3, \%43.2, \%79.6 ve \% 49.3 bulundu. Tanısal başarı ve SUVmaks arasında sınırda anlamlı istatistiksel ilişki mevcuttu ( $(=0.05$, cut-off=4.8). En yüksek tanı başarısı subkarinal lenf nodunda elde edildi (\% 77.4). Hiçbir majör komplikasyon saptanmadı.

Sonuç: K-TBiA'nın tanısal başarısı \%71 olarak bulundu. En az bir tanısal sitoloji sonucu olarak tanı alan hasta yüzdesi \% 77 idi. En sık konan tanılar malignite ve granülomatöz inflamasyondu. Örneklenen LN sayısı, LN çapı ve SUVmaks değeri arttıkça K-TBIA tanı başarısı artmaktaydı. K-TBİA güvenli bir tanısal yöntemdir.

Anahtar kelimeler: K-TBIA, mediyasten, lenf nodu, malignansi, granülomatöz inflamasyon

\section{INTRODUCTION}

Transbronchial needle aspiration (TBNA) is a minimally invasive technique for lymph node (LN) sampling to investigate etiologies of mediastinal and hilar LNs. Although TBNA was firstly described in 1949, fiberoptic bronchoscopic application was defined in $1981(1,2)$. Besides conventional usage with white light bronchoscopy (C-TBNA), its bronchoscopic appliance can also be guided by newer imaging methods like endobronchial ultrasound (EBUS-TBNA).

Conventional TBNA is a minimally invasive, safe, and cost-effective technique in evaluating mediastinal and enlarged LNs. Emergence and increasing use of EBUSTBNA provided more information about this newer technique's diagnostic success and gave the opportunity to compare it with that of C-TBNA. The meta-analyses performed for the $3^{\text {rd }}$ edition of American College of Chest Physicians (ACCP) Diagnosis and Management of Lung Cancer Guideline yielded mean pooled sensitivities of $78 \%$ and $89 \%$ for C-TBNA and EBUSTBNA, respectively (3). There are randomized trials with results suggesting better diagnostic results with EBUS-TBNA in both lung cancer and sarcoidosis patients (4-6). Despite better diagnostic results of TBNA with additional imaging, requirement for advanced devices, special equipment and experienced staff for the specific procedure makes wide range application of those techniques uneasy (7). Thus, C-TBNA may still be important for LN sampling in terms of feasibility and practicality. Herein we report the diagnostic yield (DY) and safety of C-TBNA performed in a single center at a university clinic.

\section{PATIENTS and METHODS}

\section{Patients}

The study included 363 consecutively performed C-TBNA procedures in 219 patients who underwent fiberoptic bronchoscopy and C-TBNA in the Bronchoscopy Unit of Hacettepe University Adult Hospital between October $1^{\text {st }}, 2012$ and December $31^{\text {st }}, 2014$. With the retrospective design, the study was approved by Hacettepe University Non-interventional Clinical Researches Ethical Committee. The files of the patients were reviewed retrospectively and available study forms were duly filled in. The age, gender, radiological findings, bronchoscopic findings, sampled LN stations, complications related to procedure, cytological findings, and final diagnoses were recorded on these forms. If available, short axis diameter on computed tomography (CT) of thorax and maximum standardized uptake values (SUVmax) on integrated positron emission tomography and CT (PET/CT) were recorded for $\mathrm{LNs}$ that were sampled by $\mathrm{C}-\mathrm{TBNA}$.

\section{C-TBNA Procedure}

Conventional TBNAs were performed by experienced bronchoscopists and residents under their supervision. The procedures were performed with 22-gauge cytology needles of two brands: 1) Wang MW-122 of Bard-Wang, Billerica, Mass., USA, 2) Matek TBN0122 of Matek Medical, Ostim, Ankara, Turkey. Procedures were performed without an on-site cytopathologist. Although exact numbers weren't recorded, all LN stations were sampled at least three times. The aspirates were rapidly placed on a glass slide, which was then covered with a second slide, and while applying minimal continuous pressure, the slides were drawn apart. After air-drying, the smears were transported to the cytopathology unit for staining and evaluation. Air-dried slides were stained with MayGrünwald Gimsa (MGG) stain.

\section{Cytological Assessments}

All cytological samples were evaluated by a single experienced cytopathologist. If more than one station 
was sampled in a patient, each station's cytological result was recorded separately. Cytological samples were considered as diagnostic if they represented a lymph node, which is characterized by the presence of abundant lymphoid cells of polymorphous appearance. Cytological results revealing malignant cells and granulomatous inflammation were considered as specifically diagnostic for a pathological process. Cytological results revealing polymorphous lymphocytes without any other findings like granulomatous inflammation or malignant cells were also considered as diagnostic, but represented a reactionary lymph node. Cytological results revealing only bronchial epithelial cells, mucus, blood elements or inadequate cytological material were considered as non-diagnostic. Such cases were already categorized as non-diagnostic with a note on cytology reports. If cytological findings revealed specific malignancy types, these results were also recorded.

\section{Statistical Analysis}

Statistical analyses were performed by using IBM SPSS for Windows Version 21.0 statistical software package. Continuous variables presented as mean \pm standard deviation (minimum-maximum). Categorical variables summarized as frequencies and percentages. Normality of the continuous variables was evaluated by Shapiro Wilks test. Differences between groups according to categorical variables were determined by chi-square and Fisher's exact tests and differences between the two groups according to continuous variables were determined by Mann-WhitneyWilcoxon test. Pearson correlation coefficient was used to show the relation between continuous variables. ROC curve analysis was used to show the diagnostic value of TBNA for certain LN diameter cutoff values. The sensitivity (SEN), specificity (SPE), negative predictive and positive predictive values (NPV and PPV) were calculated for these cut-offs. A p value less than 0.05 described as statistically significant.

\section{RESULTS}

The study included 219 patients (male/female: 148/71, mean age: $57 \pm 13.6$ years). Of 363 C-TBNA procedures, sampled stations were subcarinal in $164(45.2 \%)$, right paratracheal in $121(33.3 \%)$, right hilar in $58(16 \%)$, left hilar in $13(3.6 \%)$, and left paratracheal in $7(1.9 \%)$ (Table 1). The DY of C-TBNA was $77.4 \%$ in subcarinal, $64.5 \%$ in right paratracheal, $71.4 \%$ in left paratracheal, $67.2 \%$ in right hilar, and $61.5 \%$ in left hilar $\mathrm{LNs}$. There was no statistically significant relationship between DY and sampled LN station $(p=0.12)$. Conventional TBNA was diagnostic in $257(71 \%)$ and non-diagnostic in 106 $(29 \%)$ LNs. The diagnoses were malignancy in 109 $(30 \%)$, granulomatous inflammation in $68(18.7 \%)$, cystic fluid aspiration in $2(0.6 \%)$, and reactionary lympadenopathy in $78 \mathrm{LNs}(21.5 \%)$ (Table 2$)$. A specific diagnostic result was obtained in 179 (49.3\%) procedures totally. Of these procedures, $109(30 \%)$ were malignancy and $70(19.3 \%)$ were benign disorders. The procedures revealing granulomatous inflammation were compatible with sarcoidosis in 61, tuberculosis in 3, and granulomatous inflammation accompanied by malignancy in 4 procedures In Figure 1 , the CT sections and cytological examinations of three patients with the diagnoses of adenocarcinoma, squamous cell carcinoma and sarcoidosis are presented.

Table 1. Characteristics of sampled LNs

\begin{tabular}{|c|c|c|c|c|c|c|}
\hline \multirow[b]{2}{*}{ LN station } & \multirow[b]{2}{*}{ n (\%) } & \multirow[b]{2}{*}{$\begin{array}{c}\text { Diagnostic } \\
\text { yield } \\
\text { n }(\%)\end{array}$} & \multicolumn{2}{|c|}{ Diameter } & \multicolumn{2}{|c|}{ SUVmax on PET/CT } \\
\hline & & & $\begin{array}{c}\text { LNs with a } \\
\text { measured } \\
\text { diameter } \mathrm{n}(\%)\end{array}$ & $\begin{array}{c}\text { Mean } \pm \text { SD } \\
(\mathrm{mm})(\text { Range })\end{array}$ & $\begin{array}{c}\text { LNs with } \\
\text { measured } \\
\text { SUVmax n (\%) }\end{array}$ & $\begin{array}{c}\text { Mean } \pm \text { SD } \\
\text { (Range) }\end{array}$ \\
\hline Subcarinal & $164(45.2)$ & $127(77.4)$ & $146(89)$ & $17 \pm 10.3(5-100)$ & $61(37.2)$ & $7.77 \pm 3(2.6-12)$ \\
\hline Right paratracheal & $121(33.3)$ & $78(64.5)$ & $101(83.4)$ & $16.1 \pm 8.9(6-51)$ & $50(41.3)$ & $7.84 \pm 8.8(1-62)$ \\
\hline Right hilar & $58(16)$ & $39(67.2)$ & $38(65.5)$ & $17.3 \pm 7.1(7-43)$ & $11(18.9)$ & $7.40 \pm 4.2(1.85-15)$ \\
\hline Left hilar & $13(3.6)$ & $8(61.5)$ & 7 (53.8) & $15.6 \pm 7.4(7-30)$ & $4(30.7)$ & $8.35 \pm 4.2(4-14)$ \\
\hline Left paratracheal & $7(1.9)$ & $5(71.4)$ & $5(71.4)$ & $17.6 \pm 6.3(12-27)$ & $1(14.2)$ & 7.2 \\
\hline All & $363(100)$ & $257(71)$ & $297(81.8)$ & $16.7 \pm 9.3(5-100)$ & $127(34.9)$ & $7.78 \pm 7(1-62)$ \\
\hline
\end{tabular}




\begin{tabular}{|lcc|}
\hline \multicolumn{3}{|l|}{ Table 2. The cytological results of C-TBNA procedures } \\
\hline Cytological result & $\mathbf{n}$ & $\mathbf{\%}$ \\
\hline Diagnostic & 257 & 71 \\
Malignancy & 109 & 30 \\
Malignant epithelial cells & 31 & 8.5 \\
Non-small cell lung cancer & 27 & 7.4 \\
Adenocarcinoma & 26 & 7.2 \\
Small cell lung cancer & 19 & 5.2 \\
Squamous cell lung cancer & 3 & 0.8 \\
Neuroendocrine tumor & 1 & 0.3 \\
Metastasis of testis tumor & 1 & 0.3 \\
Reactionary LNs & 78 & 21.5 \\
Granulomatous inflammation & 68 & 18.7 \\
Sarcoidosis & 61 & 16.8 \\
Tuberculosis & 3 & 0.8 \\
Accompanied by malignancy & 4 & 1.1 \\
Cystic fluid aspiration & 2 & 0.6 \\
Non-diagnostic & 106 & 29 \\
Total & 363 & 100 \\
\hline
\end{tabular}

LN: Lymph node, C-TBNA: Conventional transbronchial needle aspiration.

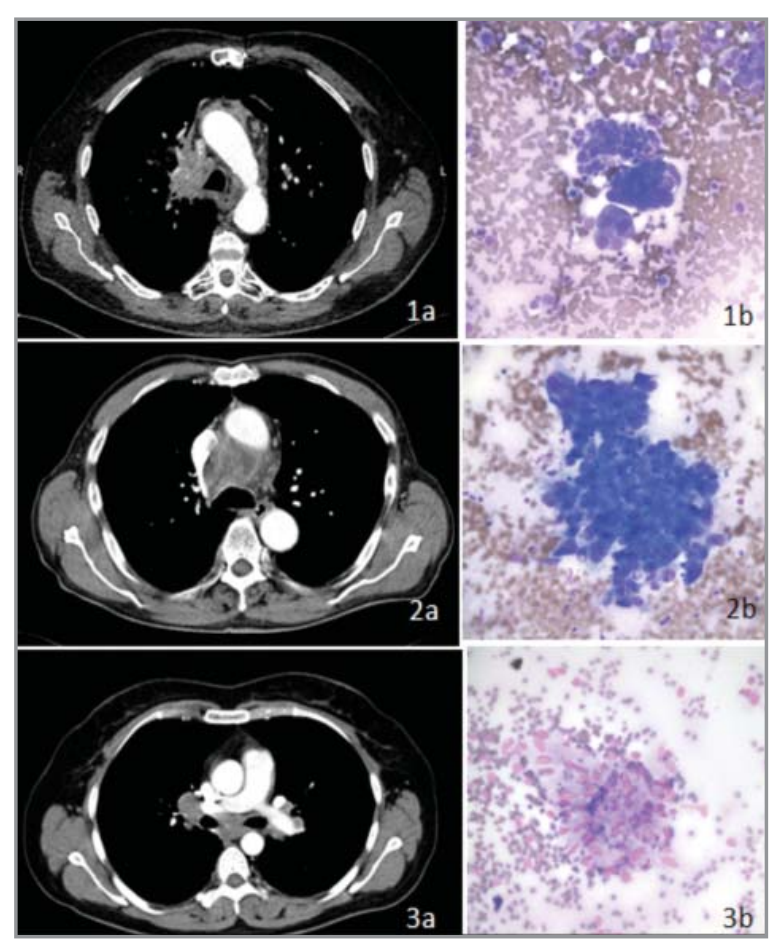

Figure 1. The CT sections and cytological examinations of three patients. Patient 1 presented with right hilar mass and right lower paratracheal LN on CT (1a), the cytology of C-TBNA revelaed adenocarcinoma (1b). Patient 2 presented with mediastinal enlarged LNs on CT (2a), the cytology of C-TBNA revelaed squamous cell carcinoma (2b). Patient 3 presented with right hilar and mediastinal enlarged LNs on CT (3a), the cytology of C-TBNA revelaed granulomatous inflammation (3b).
Conventional TBNA provided diagnostic samples at least from one LN in 168 (77\%) of 219 patients (Table $3)$. The number of sampled LNstations was one in $105(47.9 \%)$, two in 84 (38.4\%), and three in 30 $(13.7 \%)$ patients. There was a statistically significant relationship between DY and number of sampled LN stations $(p=0.033)$. Diagnostic yield was $69.5 \%$ for patients with one sampled LN station, $81 \%$ for patients with two sampled LN stations, and 91\% for patients with three sampled LN stations.

Reviewing the files we reached the diameters of 297 LNs. The diameter was > $15 \mathrm{~mm}$ in 153 (51.5\%) LNs. Mean diameter was $16.7 \pm 9.4 \mathrm{~mm}$ (Range: 5-100). Mean diameters of diagnostic and non-diagnostic LNs was significantly different (17.7 vs $14.2 \mathrm{~mm}, \mathrm{p}<$ 0.001). Diagnostic yield of C-TBNA according to $\mathrm{LN}$ diameter is presented in Table 4. Considering all LNs, a cut-off diameter of $11.5 \mathrm{~mm}$ or higher was suggestive to be diagnostic with a SEN, SPE, PPV, and NPV of $83.3 \%, 43.2 \%, 79.6 \%$, and $49.3 \%$, respectively $(p<$ 0.001). The cut-off diameter was $10.5 \mathrm{~mm}$ for subcarinal LN with a SEN, SPE, PPV, and NPV of $90.4 \%, 41.9 \%, 85.2 \%$, and $54.2 \%$, respectively $(p=$ 0.007). In individual analysis of remaining stations, there was no significant relationship between LN diameter and DY.

Diagnostic yield of C-TBNA according to SUVmax values are presented in Table 4. Uptake values were obtained in 127 LNs. Considering all LNs, there was a nearly statistically significant relationship between SUVmax value and DY of C-TBNA ( $p=0.05)$. A cutoff value for SUVmax 4.8 or higher was suggestive to be diagnostic with a SEN, SPE, PPV, and NPV of $71.7 \%, 51.4 \%, 79.5 \%$, and $51.4 \%$, respectively. There was a more statistically significant relationship between SUVmax value and DY of C-TBNA at the right paratracheal region $(p=0.035)$. The cut-off value for SUVmax at the right paratracheal region was 4.9 with a SEN, SPE, PPV, and NPVof $74.2 \%, 63.2 \%$, $76.7 \%$, and $60 \%$ respectively.

Table 3. Diagnostic yields according to number of sampled
LNs
\begin{tabular}{|lccc|}
$\begin{array}{l}\text { Number of } \\
\text { sampled LNs }\end{array}$ & $\mathbf{n}(\%)$ & $\begin{array}{c}\text { Diagnostic } \\
\text { yield } \mathbf{n}(\%)\end{array}$ & p value \\
\hline 1 & $105(48)$ & $73(70)$ & 0.033 \\
2 & $84(38)$ & $68(81)$ & \\
3 & $30(14)$ & $27(90)$ & \\
Total & $219(100)$ & $168(77)$ & \\
\hline LN: Lymph node. & & \\
\hline
\end{tabular}




\begin{tabular}{|c|c|c|c|}
\hline Cut-off values & n (\%) & $\begin{array}{c}\text { Diagnostic yield } \\
\text { n (\%) }\end{array}$ & p value \\
\hline \multicolumn{4}{|c|}{ Diameter (All stations) } \\
\hline$\leq 11.5 \mathrm{~mm}$ & $71(23.9)$ & $36(50.7)$ & $<0.001$ \\
\hline$>11.5 \mathrm{~mm}$ & $226(76.1)$ & $180(79.6)$ & \\
\hline \multicolumn{4}{|c|}{ Diameter (Subcarinal) } \\
\hline$\leq 10.5 \mathrm{~mm}$ & $24(16.4)$ & $11(45.8)$ & 0.007 \\
\hline$>10.5 \mathrm{~mm}$ & $122(83.6)$ & $104(85.2)$ & \\
\hline \multicolumn{4}{|c|}{ SUVmax (All stations) } \\
\hline$\leq 4.8$ & $44(34.6)$ & $26(59.1)$ & 0.05 \\
\hline$>4.8$ & $83(65.4)$ & $66(79.5)$ & \\
\hline \multicolumn{4}{|c|}{ SUVmax (Right paratracheal) } \\
\hline$\leq 4.9$ & $20(40)$ & $8(40)$ & 0.035 \\
\hline$>4.9$ & $30(60)$ & $23(76.7)$ & \\
\hline
\end{tabular}

Apart from minor bleeding at biopsy sites, no major complication occurred due to C-TBNA.

\section{DISCUSSION}

In this study, we retrospectively reviewed 363 consecutive C-TBNA procedures in 219 patients. The primary aim was to evaluate the DY of C-TBNA and after that to evaluate the association of DY with the location of LN, the shortest diameter, SUVmax of LN, and the number of sampled stations. We did not verify all of our results with invasive methods such as mediastinoscopy or surgery, since the primary aim was to find out the characteristics of LNs that we are capable of sampling adequately for diagnosis. For this reason cytological results revealing abundant polymorphic lymphocytes representing LN were also considered as diagnostic. It is a reality that this group might contain false negative diagnoses, since C-TBNA is just a diagnostic procedure with a low sensitivity, but $100 \%$ specificity (3). The DY of 363 procedures in 219 patients was $71 \%$. The ratio of patients with at least one diagnostic C-TBNA procedure was $77 \%$. While the ratio of procedures with a specific diagnosis was $49.3 \%$, the ratio of benign reactionary $\mathrm{LNs}$ was $21.5 \%$.

Conventional TBNA has been proven to be a safe, minimally invasive, and cost-effective technique for sampling mediastinal LNs. In addition to the equipment needed for bronchoscopy, TBNA needles are used. These needles are designed to pass through a bronchoscope without causing damage and are flexible enough to facilitate the positioning of the bronchoscope, yet rigid enough to penetrate the airway wall. There are two types of TBNA needles known as flexible cytology and rigid histology needles. In a prospective study including 138 consecutive patients with bronchogenic carcinoma and amenable to surgical procedures, all $8 \mathrm{~mm}$ and larger mediastinal/hilar LNs determined before bronchoscopy by CT were sampled by 18-gauge rigid and 21-gauge flexible TBNAs in the same session. The sensitivities of rigid and flexible TBNAs were 74 and $70 \%$, respectively ( $p>0.05$ ), but both had a specificity of $100 \%$ (8). In another study investigating the diagnostic value of 22-gauge Wang TBNA cytology needles in patients with mediastinal and/or hilar adenopathy, adequate lymph node sampling was obtained from 59 of 60 patients (98\%), a specific diagnosis was obtained in 45 of 60 patients $(75 \%)$ (9). In this study, we also used 22-gauge flexible cytology needles.

The DY of C-TBNA varies considerably among various studies. ACCP 2013 guideline for lung cancer found a mean pooled sensitivity of C-TBNA as $78 \%$, ranging from 14 to $100 \%$ in terms of lung cancer (3). Studies including patients with suspicion of sarcoidosis have diagnostic sensitivities ranging from 72 to $90 \%$ (10-12). In a study including 34 patients, C-TBNA revealed a definite diagnosis in 14 patients $(41.1 \%)$ and C-TBNA had a higher DY for malignancy $(64.7 \%)$ compared to non-malignant diseases $(17.6 \%)$ (13). Although our study included an unselected patient population in terms of suspected etiology, our DY of $71 \%$ is similar to results in the literature. The 
most frequent diagnoses were malignancy followed by granulomatous inflammation. Based on these findings, we claim that C-TBNA should be considered in the diagnosis of mediastinal and hilar LNs before other more invasive procedures such as mediastinoscopy or surgery.

There are substantial amount of studies in the literature to investigate predictors of diagnostic C-TBNA. Those studies differ in terms of study designs (e.g. retrospective studies, prospective case series, and randomized controlled trials) and selected patient populations. Some of the studies include unselected patient populations whereas others include patients with specific etiologies like malignancy or sarcoidosis. Systematic review of Bonifazi et al. aiming to identify predictors successful TBNA aspirations and to definet hose predictors for different patient populations found LN size ( $\geq 2 \mathrm{~cm}$ for several studies), type of disease, operator experience, endoscopic findings, needle size, number of needle passes ( $>3$ ), and LN station (subcarinal and right paratracheal) as factors with strong predictive roles for unselected population (7). In another study investigating the DY of C-TBNA by size, the DY was $0 \%$ when the LN diameter was < $2 \mathrm{~cm}, 63.6 \%$ when $\geq 2 \mathrm{~cm}$ (13). In our study, there was no significant relationship between sampled LN station and DY. But the cut-off values $11.5 \mathrm{~mm}$ for all $\mathrm{LNs}$ and $10.5 \mathrm{~mm}$ for subcarinal LN were lower than $2 \mathrm{~cm}$. Mean LN diameters were significantly different between diagnostic and non-diagnostic results (17.7 vs $14.2 \mathrm{~mm}, \mathrm{p}<0.001)$. The cut-off diameters for certain stations are important for choosing the sampling procedure EBUS-TBNA for smaller LNs, C-TBNA for larger ones.

In this study, we performed C-TBNAs from subcarinal, paratracheal, and hilar LNs. Subcarinal region was there most commonly sampled station and our best diagnostic results were achieved in there subcarinal station $(77.4 \%)$. This result is probably due to two reasons. Firstly, based on technical reasons it is easy to sample subcarinal LNs. Secondly, it is important to sample subcarinal LNs for lung cancer staging as it indicates N2 disease (14). There was also a significant relationship between number of sampled LNs and DY $(p=0.033)$. This finding indicates the importance of sampling more than one station for patients with LAPs in different stations if technically available.

As an advanced imaging method, PET/CT is increasingly used for radiological staging of lung cancer. There are studies with results suggesting increased DY of C-TBNA with higher SUVmax on $\mathrm{PET} / \mathrm{CT}$, but these studies define diverse range of SUVmax cut-offs such as 2.5, 3 and 5 (15-17). In this study, a limited percentage of patients (34.9\%) had undergone PET/CT. There was a better DY with increasing SUVmax on PET/CT with a nearly significant relationship for a cut-off SUVmax 4.8.

Conventional TBNA is known as a safe procedure with a very low incidence of complications. The most common potential complications are bleeding, pneumothorax, or pneumomediastinum. Significant bleeding rarely occurs even after a major vessel puncture. Meta-analysis of Holty et al. found overall major complication rate (two major bleeds and one pneumothorax requiring chest tube) as $0.26 \%$ (18). Fever, bacteremia and hemomediastinum are other reported complications after TBNA procedures $(19,20)$. In our study there was no major complication occurred due to C-TBNA.

Conventional TBNA has been used for over 30 years to obtain histologic and cytological specimens from mediastinal LNs with sensitivities approaching 80-90\% (3). Recently EBUS-TBNA has demonstrated even higher sensitivities among experts $(21,22)$. However EBUS-TBNA is more complicated, requires additional training, less well tolerated by patients and more costly than C-TBNA (23).

Our study's strengths include similarity of bronchoscopist experience for each procedure, analysis of both malignant and non-malignant cytologies and evaluation of cytologic samples by the same experienced cytopathologist. Retrospective basis of our study is one of the limitations. Also, results didn't include any comparison between C-TBNA results with invasive pathological sampling methods like mediastinoscopy or thoracotomy. Analyses were mainly done to evaluate sampling success, thus adequate samples without any specific diagnoses may require further diagnostic procedures. Procedurerelated factors like endoscopic findings, needle brand, number of needle passes weren't analyzed. Also there wasn't any analysis based on pre-procedural suspected etiology and final diagnosis of patient.

\section{CONCLUSION}

Conventional TBNA is an effective and safe procedure for investigating both malignant and non-malignant etiologies of mediastinal and hilar LNs. Diagnostic success of procedure is increased with number of 
sampled LNs, larger LN diameter (> $11.5 \mathrm{~mm}$ ) and increased SUVmax on PET/CT. Despite its feasibility advantages, results of studies comparing EBUS-TBNA and C-TBNA favor EBUS-TBNA in terms of diagnostic yield. In current conditions, further investigations and studies may be conducted to improve EBUSTBNA's wide range application. With decreasing trend of clinical usage of C-TBNA, it may keep its importance for settings with limited resources.

\section{ACKNOWLEDGMENTS}

This study was presented in a poster discussion session (PA313) at the annual congress of European Respiratory Society, September 26-30, 2015, Amsterdam, Netherlands.

\section{REFERENCES}

1. Schieppati E. La puncion medistinal a traves del espolon traqueal. Rev Asoc Med Argent 1949;663:497-9.

2. Wang KP, Marsh BR, Summer WR, Terry PB, Erozan YS, Baker RR. Transbronchial needle aspiration for diagnosis of lung cancer. Chest 1981;80:48-50.

3. Silvestri GA, Gonzalez AV, Jantz MA, Margolis ML, Gould $M K$, Tanoue $L T$, et al. Methods for staging non-small cell lung cancer: Diagnosis and management of lung cancer, $3^{\text {rd }} \mathrm{ed}$ : american college of chest physicians evidence-based clinical practice guidelines. Chest 2013;143(suppl 5):e211S-e50S.

4. Herth F, Becker HD, Ernst A. Conventional vs endobronchial ultrasound-guided transbronchial needle aspiration: a randomized trial. Chest 2004;125:322-5.

5. Oki M, Saka H, Kitagawa C, Tanaka S, Shimokata T, Kawata $Y$, et al. Real-time endobronchial ultrasound-guided transbronchial needle aspiration is useful for diagnosing sarcoidosis. Respirology 2007;12:863-8.

6. Gupta D, Dadhwal DS, Agarwal R, Gupta N, Bal A, Aggarwal AN. Endobronchial ultrasound-guided transbronchial needle aspiration vs conventional transbronchial needle aspiration in the diagnosis of sarcoidosis. Chest 2014;146:547-56.

7. Bonifazi M, Zuccatosta L, Trisolini R, Moja L, Gasparini S. Transbronchial needle aspiration: a systematic review on predictors of a successful aspirate. Respiration 2013;86:123-34.

8. Bilaçeroğlu S, Cagirici U, Günel O, Bayol U, Perim $K$. Comparison of rigid and flexible transbronchial needle aspiration in the staging of bronchogenic carcinoma. Respiration 1998;65:441-9.

9. Cetinkaya E, Yildiz P, Altin S, Yilmaz V. Diagnostic value of transbronchial needle aspiration by Wang 22-gauge cytology needle in intrathoracic lymphadenopathy. Chest 2004; 125:527-31.
10. Wang KP, Fuenning C, Johns CJ, Terry PB. Flexible transbronchial needle aspiration for the diagnosis of sarcoidosis. Ann Otol Rhinol Laryngol 1989;98(4 Pt 1):298-300.

11. Trisolini R, Lazzari Agli L, Cancellieri A, Poletti V, Tinelli C, Baruzzi $G$, et al. The value of flexible transbronchial needle aspiration in the diagnosis of stage I sarcoidosis. Chest 2003; 124:2126-30.

12. Trisolini R, Tinelli C, Cancellieri A, Paioli D, Alifano $M$, Boaron $M$, et al. Transbronchial needle aspiration in sarcoidosis: yield and predictors of a positive aspirate. $J$ Thorac Cardiovasc Surg 2008;135:837-42.

13. Kupeli E, Memis L, Ozdemirel TS, Ulubay G, Akcay S, Eyubog/u FO. Transbronchial needle aspiration "by the books". Ann Thorac Med 2011;6:85-90.

14. Goldstraw P. Staging manual in thoracic oncology. Orange Park, Florida: Editorial Rx Press;2009.

15. Hsu L-H, Ko J-S, You D-L, Liu C-C, Chu N-M. Transbronchial needle aspiration accurately diagnoses subcentimetre mediastinal and hilar lymph nodes detected by integrated positron emission tomography and computed tomography. Respirology 2007; 12:848-55.

16. Borekci S, Elbek O, Bayram N, Uysal N, Bakir K, Zincirkeser $S$, et al. Combined transbronchial needle aspiration and PET/CT for mediastinal staging of lung cancer. Tuberk Toraks 2011;59:55-61.

17. Seijo LM, Campo A, de Torres JP, Lozano MD, Martino E, Bastarrika G, et al. FDG Uptake and the diagnostic yield of transbronchial needle aspiration. I Bronchology Interv Pulmonol 2011;18:7-14.

18. Holty JE, Kuschner WG, Gould MK. Accuracy of transbronchial needle aspiration for mediastinal staging of non-small cell lung cancer: a meta-analysis. Thorax 2005;60:949-55.

19. Witte MC, Opal SM, Gilbert JG, Pluss JL, Thomas DA, Olsen $J$, et al. Incidence of fever and bacteremia following transbronchial needle aspiration. Chest 1986;89:85-7.

20. Lazzari Agli L, Trisolini R, Burzi M, Patelli M. Mediastinal hematoma following transbronchial needle aspiration. Chest 2002;122:1106-7.

21. Yasufuku K, Chiyo M, Sekine Y, Chhajed PN, Shibuya K, lizasa $T$, et al. Real-time endobronchial ultrasound-guided transbronchial needle aspiration of mediastinal and hilar lymph nodes. Chest 2004; 126:122-8.

22. Herth FJ, Becker HD, Ernst A. Ultrasound-guided transbronchial needle aspiration: an experience in 242 patients. Chest 2003;123:604-7.

23. Medford AR, Agrawal S, Free CM, Bennett JA. A prospective study of conventional transbronchial needle aspiration: performance and cost utility. Respiration 2010;79:482-9. 